\title{
The Effect of Microwave Treatment on Germination, Vigour and Health of China Aster (Callistephus chinensis Nees.) Seeds
}

\author{
Feng Han \\ Forest Inventory and Planning Institute of Sichuan Province \\ Chengdu, 610081, China \\ E-mail: hanfengxj@163.com
}

\begin{abstract}
The purpose of this research was to study effects of microwave treatment on China aster seed germination, vigour and infestation with fungi, at temperature $20^{\circ} \mathrm{C}$. The seeds were treated in microwave oven (power $850 \mathrm{~W}$ heating power) in dry conditions and in water for 10, 20,30, 40, 50, 60, 90, 120 and 180 s respectively.
\end{abstract}

Keywords: China aster seeds, Microwave treatment, Germination, Vigour, Health

\section{Introduction and literature review}

With the development of the flower industry, some producers have been doing research, answering the question: how to develop the new varieties and how to improve the quality of flower seeds? The most important problems are that flower seed retaining some characteristics typical for wild species such as dormancy and wide range of seed maturity at harvest. Another important problem is that some flower seeds can be easy to infect with seed-borne pathogens. Seed treatment is a common method used to improve seed quality, because is convenient, cheap and effective, it is accepted by seed producers widely.

Callistephus chinensis Nees. is more commonly known as China aster. The family has an estimated 1,150 genera and a huge number of species seen almost all over the world originating from North America, Europe, China, etc. All those varieties are divided into four main groups: needle group, peony group, chrysanthemum group and prince group. Native to Asia, this lovely flowering annual is worth the little extra effort it takes for growing. Most species of aster are perennial and generally bloom in August. They have daisy-like or star-like flower heads (4-6 cm in diameter) with a yellow center on leafy, often tall, stems. Their colors vary from white to creamy yellow, pink, blue, red and purple. They do well in beds, borders or pots and are a favorite as cut flowers because of their longevity.

The color of China aster seeds is bright brown. Seed length, width and thickness are 3.0-5.0 mm, 1.5-2.0 and 0.3-1.2 mm respectively. There are 400-500 seeds in 1 gram (Duczmal and Tucholska, 1993).

Generally, quality of China aster seed is very poor. Germination capacity standard before the Poland joint the European Union in 2004 for this species was only 45\% (Anonymous, 1990). Grzesik et al. (1998) found that the mature China aster seeds harvested in late autumn were lighter than those collected in early autumn. Seeds collected from tertiary capitula germinated worse than those collected from primary or secondary capitula.

Zhang (1997) reported that in one of the examined China aster varieties the percentage of dead seed was very high, amounted to $30 \%$.

Orlicz-Luthardt (1998) reported, after mycological analysis of manual harvested China aster seeds, that dominant fungi contaminated seed coat. The main detected fungi were as follow: A. alternata, Cephalosporium sp., Penicillium spp., Sclerotinia sclerotiorum (Lib.) de Bary, Trichothecium roseum Link Fries, B. cinerea and Fusarium oxysporum.

In order to improve the quality of China aster seeds, many methods of seed treatment had been studied. Improvement of germination by conditioning (priming) of seeds in water has been known for many years (Lang, 1965). Several methods are used for seed conditioning in order to accelerate the rate of germination and to improve seedling uniformity. These methods can be classified as biological, chemical and physical.

Priming and fungicide treatments are the most popular methods improving quality of China aster seeds. 


\section{Materials and methods}

\subsection{Materials}

\subsubsection{Seeds}

One commercial sample of China aster (Callistephus chinensis Nees.) seeds obtained from CNOS Horticultural Seed Company Ltd in Poznan was used in the study.

\subsubsection{Fungicide}

Kaptan Zawiesinowy 50 WP (a.i. captan, 50\%) was used in the experiment. The fungicide was produced by Zakłady Chemiczne „Organika-Azot” SA in Jaworzno.

\subsection{Methods}

\subsubsection{Seed treatment}

\subsubsection{Fungicide treatment}

Seeds were soaked in $0.4 \%$ solution of Kaptan Zawiesinowy 50 WP for 30 min. After the treatment seeds were surface dried between blotters.

\subsubsection{Dry microwave treatment}

$1 \mathrm{~g}$ of China aster seeds at a time was placed evenly in an open glass Petri dish and subsequently the dish was placed in the center of plate in an Ignis AKL-560 microwave oven at full strength $850 \mathrm{~W}$, for 10, 20, 30, 40, 50, $60,90,120$ and $180 \mathrm{~s}$.

\subsubsection{Seed microwave treatment in water}

$1 \mathrm{~g}$ Seeds were wrapped in cotton scarf and placed in Pyrex glass beakers containing $500 \mathrm{ml}$ of distill-water. The beaker with seeds was placed in the center of rotating plate in an Ignis AKL-560 microwave oven of a full power $850 \mathrm{~W}$, for $10,20,30,40,50,60,90,120$ and $180 \mathrm{~s}$.

After treatment seeds were chilled instantly in Pyrex glass beakers containing cold water and subsequently chilling under cold tap water for 2 min. After chilling seeds were taken out from the scarf and dried back in plastic trays lined with blotter paper at $20^{\circ} \mathrm{C}$ and $45 \%$ relative humidity for $48 \mathrm{~h}$ to equilibrium moisture content.

2.2.2 Seed quality assessment

The germination, vigour and health tests of China aster seeds were performed for:

a) untreated seeds (control I)

b) seeds treated with fungicide (control II)

c) dry microwave treated seeds

d) seeds microwave treated in water

\subsubsection{Germination test}

The germination test was conducted at $20^{\circ} \mathrm{C}$ in darkness on 6 replicates of 50 seeds. Seeds were placed in $9 \mathrm{~cm}$ diameter Petri dishes containing 6 layers of blotting paper wetted with distilled water. Moreover, after 6 and 12 days of germination, normal seedlings were evaluated according to ISTA Rules (ISTA, 1996). The seeds were incubated at $20^{\circ} \mathrm{C}$ in darkness. The percentage of normal seedlings at first count (I count) and final count (II count) presents germination capacity. Furthermore, after 12 days, abnormal seedlings, dead seeds and fresh ungerminated seeds were distinguished.

Additionally the total number of germinating seeds (maximum germination - Gmax) was evaluated using statistical program Seed Calculator 2.1 (Yalink and Van der Schoor,1999).

\subsubsection{Vigour test}

The vigour test was conducted at $20^{\circ} \mathrm{C}$ in darkness on 6 replicates of 50 seeds for each treatment. Seeds were placed in $9 \mathrm{~cm}$ diameter Petri dishes containing 6 layers of blotting paper wetted with distilled water. Seeds were considered as germination when there was a visible protrusion through the seed coat. The seeds were incubated under the same conditions like in the previous test. Germinating seeds were counted daily and removed from Petri dishes until no new germinating seeds occurred.

The following parameters were calculated using statistical program Seed Calculator 2.1 (Yalink and Van der Schoor, 1999): 
- $\mathrm{T}_{1}-$ time to $1 \%$ of Gmax

- $\mathrm{T}_{10}$ - time to $10 \%$ of $\mathrm{Gmax}$

- $\mathrm{T}_{25}$ - time to $25 \%$ of Gmax

- $\mathrm{T}_{50}$ - time to $50 \%$ of Gmax

- $\mathrm{T}_{75}$ - time to $75 \%$ of Gmax

- $\mathrm{T}_{90}$ - time to $90 \%$ of $\mathrm{Gmax}$

- MGT - mean germination time

- Uniformity I $\left(\mathrm{U}_{75-25}\right)$ - time between 25 and $75 \%$ of Gmax

- Uniformity II ( $\left.\mathrm{U}_{90-10}\right)$ - time between 90 and $10 \%$ of $\mathrm{Gmax}$

2.2.2.3 Health test

Two hundred seeds from each treatment were placed on the surface of the $9 \mathrm{~cm}$ diameter Petri dishes, 20 seeds per dish, containing 6 layers of blotting paper wetted with distilled water. The seeds were incubated at $20^{\circ} \mathrm{C}$ for $24 \mathrm{~h}$ in darkness, next at $-20^{\circ} \mathrm{C}$ for $24 \mathrm{~h}$ and then at $20^{\circ} \mathrm{C}$ for 8 days, under alternating cycle $12 \mathrm{~h}$ of near ultra violet light and $12 \mathrm{~h}$ darkness. After incubation each seed was examined thoroughly and the fungi were identified based on their habit and spore character by using a stereomicroscope and compound microscope, respectively (Agrios, 2005, Barnett and Hunter, 1987, Cappelli and Covarelli, 2005, Ellis, 1971, Malone and Muskett, 1964). A total number of seeds free from fungi for each treatment were counted.

\subsubsection{Moisture content}

For untreated and dry microwave treated seeds moisture contents were evaluated. Seed -4 replicates per $0.5 \mathrm{~g}-$ were dried at $130^{\circ} \mathrm{C}$ for $1 \mathrm{~h}$.

The seed moisture content was counted according to:

$\mathrm{W}=[(\mathrm{a}-\mathrm{b}) /(\mathrm{a}-\mathrm{c})] \cdot 100 \%$

where:

$\mathrm{a}-$ is the weight of container with seeds before drying,

$\mathrm{b}-$ is the weight of container with seeds after drying,

$\mathrm{c}-$ is the weight of container.

\subsubsection{Statistical analysis}

Seed Calculator 2.1 software developed by Plant Research International in Wageningen in the Netherlands was applied to analyze total number of germinating seeds and vigour parameters (Yalink and Van der Schoor, 1999).

Germination, vigour and health data were analyzed by means of variance analysis (ANOVA) followed by Duncan's multiple range test. Percentage was transformed according to:

$\mathrm{Y}=\operatorname{arc} \sin [\operatorname{sqr}(\mathrm{x} / 100)]$ before ANOVA.

\section{Results}

\subsection{Seed germination}

For untreated seeds the high percentage of maximum germination (total number of germinating seeds) was noted (Tab. 1). Dry microwave seed treatment for time longer than $20 \mathrm{~s}$, as well as treating seeds in water for 30, 60, 90, 120 and $180 \mathrm{~s}$, and fungicide treatment, resulted in significant decrease of this parameter. Moreover, after seed treatment in dry condition for 120 and $180 \mathrm{~s}$ and in water for $180 \mathrm{~s}$, seeds did not germinate. Germination capacity at first count decreased significantly after dry microwave seed treatment for 40, 50, 60 and 180 s, microwave seed treatment in water for $10,90,120$ and $180 \mathrm{~s}$, and after fungicide treatment.

For untreated seeds the percentage of abnormal seedling amounted to 5.3\% was noted (Tab. 2). Dry microwave seed treatment for $120 \mathrm{~s}$, as well as treating seeds in water for $30 \mathrm{~s}$, resulted in significant increase of this parameter. However, after seed treatment in dry condition and in water for $180 \mathrm{~s}$, the percentage of abnormal seedlings significantly decreased because the seeds did not germinate. For untreated seeds the percentage of dead seeds was $21.7 \%$. In general, dry microwave seed treatment for time longer than $30 \mathrm{~s}$, as well as treating seeds in water for $180 \mathrm{~s}$, negatively affected this parameter. The number of dead seeds significantly decreased after fungicide treatment and treating seeds in water for $30 \mathrm{~s}$. For untreated seeds the percentage of fresh ungerminated seeds amounted to $2.7 \%$. Dry microwave seed treatment for $20,60,120,180 \mathrm{~s}$, as well as treating 
seeds in water for 10, 30, 50, 60, 90, 120 and $180 \mathrm{~s}$ and treating seeds with Kaptan Zawiesinowy 50 WP, resulted in significant increase of this parameter (Tab. 2).

\subsection{Seed vigour}

The results obtained varied depending on the treatment methods. After treatment longer than $90 \mathrm{~s}$ and $120 \mathrm{~s}$ for dry treatment and treatment in water, respectively, germination did not occurre (Tab. 3, 4 and 5). T1 and T10 values were not significantly different after both fungicide and microwave treatment than in control (Tab. 3). Fungicide treatment significantly affected speed and uniformity of germination. Treating seeds with Kaptan Zawiesinowy 50 WP had negative effect on T25, T50, T75, T90, MGT and U90-10 values (Tab. 3, 4 and 5). T25 values were not significantly different after fungicide and both microwave treatments than in control except the treatment for $120 \mathrm{~s}$ in water, after witch the parameter increase significantly (Tab. 3). After dry treatment for $60 \mathrm{~s}$ and treatment in water for $120 \mathrm{~s}$, as well as after fungicide treatment, the T50 value increase significantly (Tab. 4). T75, T90 and MGT values increase significantly after dry microwave seed treatment for 30, 40, 60 and $90 \mathrm{~s}$, after microwave seed treatment in water for $120 \mathrm{~s}$ and after fungicide treatment (Tab. 4 and 5). U75-25 value increase significantly after dry microwave seed treatment for 40, 60 and $90 \mathrm{~s}$, microwave seed treatment in water for $120 \mathrm{~s}$ and after fungicide treatment (Tab. 5). U90-10 value increase significantly after dry microwave seed treatment for 30, 40 and $90 \mathrm{~s}$, microwave seed treatment in water for $120 \mathrm{~s}$ and after fungicide treatment (Tab. 5).

Other variants of seed treatment were not statistically different from control (Tab. 3, 4 and 5).

\subsection{Mycological analysis}

The following fungi were identified in tested seeds: Alternaria alternata (Fr.) Keissler, Cladosporium spp., Curvularia sp., Epicoccum purpurascens Ehrenb. ex Schlecht., Mucor sp, Penicillium spp., Phoma sp., Rhizopus nigricans Ehrenb. ex Corda and Ulocladium spp. Among them A. alternata, Cladosporium spp. and Penicillium spp. were occurred most frequently (Tab. 6). After fungicide treatment the number of seeds infested with A. alternata decreased from $39.0 \%$ to $9.5 \%$. Microwave treatment in dry condition for 120 and $180 \mathrm{~s}$, and in water for $60 \mathrm{~s}$ and longer, significantly decreased seeds infestation with this pathogen too. Dry microwave treatment for 20, 40 and $180 \mathrm{~s}$ and microwave seed treatment in water for 20,50 and $120 \mathrm{~s}$ eliminated completely seed infestation with Cladosporium spp. The number of seeds infested with these fungi also decreased significantly when seeds were treated with fungicide, treated with microwave in dry condition for $30 \mathrm{~s}$ and microwave treated in water for 40 and $90 \mathrm{~s}$. Meanwhile, number of seeds infested with fungi belonging to Penicillium genera increased significantly when seeds were treated for $50 \mathrm{~s}$ in dry condition and $10 \mathrm{~s}$ in water (Tab. 6). No differences in levels of seeds infestation with Epicoccum purpurascens and Mucor sp. were observed opposite of treatment used. The number of seeds infested with Rhizopus nigricans increase after dry microwave seed treatment for $60 \mathrm{~s} \mathrm{(Tab.} \mathrm{7).} \mathrm{Fungi} \mathrm{Curvularia} \mathrm{sp.} \mathrm{and} \mathrm{Ulocladium} \mathrm{spp.} \mathrm{were} \mathrm{not} \mathrm{noted} \mathrm{in} \mathrm{untreated} \mathrm{seeds.} \mathrm{Dry}$ microwave treatment for $60 \mathrm{~s}$ resulted in $2.0 \%$ infestation of seeds with Curvularia sp. The same treatment for 10 , 20, 30 and 50 s increase significantly seed infestation with Ulocladium spp. (Tab. 8).

The tested sample was characterised with high percentage of seeds free from fungi, amounted to $53.3 \%$ Moreover, dry seed microwave treatment for 120 and $180 \mathrm{~s}$, microwave treatment in water for 90, 120, $180 \mathrm{~s}$ and fungicide treatment resulted in significant increase of number of seeds free from fungi (Tab. 8).

\subsection{Seed moisture content}

Moisture content analyses were performed for untreated seeds and dry microwave treated seeds. Untreated seeds showed highest moisture content, at the level of $6.60 \%$. Prolongation of exposition time after dry microwave seed treatment caused decrease of seed moisture content from $6.48 \%$ to $4.70 \%$ after $10 \mathrm{~s}$ and $180 \mathrm{~s}$ treatment, respectively.

\section{Conclusions}

1. Treating seeds in dry condition for 120 and $180 \mathrm{~s}$ and in water for $180 \mathrm{~s}$, resulted in loss of seed viability.

2. Dry microwave seed treatment for time longer than $20 \mathrm{~s}$ negatively influenced total number of germinating seeds. Seeds treated in water maintain high values of maximum germination up to $90 \mathrm{~s}$ of exposition.

3. In general, microwave treatment had no positive effect on seed vigour. Sometimes even prolong germination and negatively affected uniformity of germination, especially after treatment in dry conditions.

4. Treating seeds with Kaptan Zawiesinowy $50 \mathrm{WP}$ control seed infestation with fungi most effectively then both microwave seed treatments, however, negatively influenced mean germination time and uniformity of 
germination.

5. Except Alternaria alternata other fungi infested the seeds in a small extent.

6. Microwave China aster seed treatment in water for $60 \mathrm{~s}$ significantly decreased the number of seeds infested with $A$. alternata, without negative effect on germination capacity.

Along with prolongation of the time of dry microwave treatment decrease of seed moisture content was observed.

\section{Summary}

The purpose of this research was to study effects of microwave treatment on China aster seed germination, vigour and infestation with fungi, at temperature $20^{\circ} \mathrm{C}$. The seeds were treated in microwave oven (power $850 \mathrm{~W}$ heating power) in dry conditions and in water for 10, 20,30,40, 50, 60, 90, 120 and 180 s respectively.

The germination, vigour and health tests of China aster seeds were performed for: untreated seeds, seeds treated with $0.4 \%$ solution of Kaptan Zawiesinowy $50 \mathrm{WP}$ for $30 \mathrm{~min}$, dry microwave treated seeds and seeds treated in water. Additionally for untreated seeds and dry treated seeds moisture content was determined.

Treating seeds in dry condition for 120 and $180 \mathrm{~s}$ and in water for $180 \mathrm{~s}$, resulted in loss of seed viability. Dry microwave seed treatment for time longer than $20 \mathrm{~s}$ negatively influenced total number of germinating seeds. Seeds treated in water maintain high values of maximum germination up to $90 \mathrm{~s}$ of exposition. In general, microwave treatment had no positive effect on seed vigour. Sometimes even prolonged germination and negatively affected uniformity of germination, especially after treatment in dry conditions. Treating seeds with Kaptan Zawiesinowy 50 WP control seed infestation with fungi most effectively then both microwave seed treatments, however, negatively influenced mean germination time and uniformity of germination.

Except Alternaria alternata other fungi infested the seeds in a small extent. Microwave China aster seed treatment in water for $60 \mathrm{~s}$ significantly decreased the number of seeds infested with A. alternata, without negative effect on germination capacity.

Along with prolongation of the time of dry microwave treatment decrease of seed moisture content was observed.

\section{References}

Anonymous. (1990). Materiał siewny. Nasiona roślin kwiaciarskich Norma Branżowa BN-90/9117-01. Polski Komitet Normalizacyjny, Warszawa.

Badek, B., van Duijn, B. \& Grzesik, M. (2007). Effects of water supply methods and incubation on germination of China aster (Callistephus chinensis) seeds. Seed Science and Technology, 35 (3): 569-576.

Burth, U., Gaber, K., Jahn, M., Lindner, K., Motte, G., Panzer, S., Pflaumbaum, J. \& Scholze, F. (1991). Seed treatment with electron beams - a new method for the control of seedborne pathogens on winter wheat. Nachrichtenblatt des Deutschen Pflanzenschutzdienstes, 43: 41-45.

Barnett, H. L. \& Hunter, B. B. (1987). Illustrated Genera of Imperfect Fungi. Fourth Edition. Macmillan Publishing Company, New York, Collier Macmillan Publishers, London.

Cook, R. J. (1993). Making greater use of introduced microorganisms for biological control of plant pathogens. Annual Review of Phytopathology, 31: 53-151.

Duczmal, K. W. \& Tucholska, H. (1993). Nasiennictwo ogrodnicze. Vol. I and II. Wydawnictwa Dydaktyczne Akademii Rolniczej w Poznaniu.

Ellis, M. B. (1971). Dematiaceous Hyphomycetes. CAB, Commonwealth Mycological Institute, Kew, Surrey, England.

Grzesik, M., Górnik, K. \& Chojnowski, M. G. (1998). Effect of harvest time on the quality of Callistephus chinensis Nees. cv. Aleksandra seeds collected from different parts of plant. Seed Science and Technology, 26: 131-140.

Grzesik, M., Dawidowicz-Grzegorzewska, A. \& Górnik, K. (2000). Effects of matriconditioning with Micro-Cel-E of Callistephus chinensis L. seeds on germination, seedling emergence, stress tolerance and some metabolic events. ISHS Acta Horticulturae 517, XXV International Horticultural Congress, Part 7: Quality of Horticultural Products. [Online] Available: http://www.actahort.org/books/517/517_14.htm.

Harman, G. E. \& Nelson, E. B. (1994). Mechanisms of protection of seed and seedlings by biological seed treatments: implications for practical disease control. In: Seed Treatment: Progress and Prospects, Mono. 57, 
BCPC, Thornton Health, UK: 283-292.

Honervogt, B. \& Lehmann-Danzinger, H. (1992). Comparison of thermal and chemical treatment of cotton seed to control bacterial blight (Xanthomonas campestris pv. malvacearum). Journal of Phytopathology, 134: 103-109.

ISTA. (1996). International rules for seed testing. Seed Science and Technology. 24.

Lang, A. (1965). Effects of some internal and external conditions on seed germination. Encyclopedia of Plant Physiology, 15 (2): 848-893.

McDonald, M. B. (1999). Seed deterioration: physiology, repair and assessment. Seed Science and Technology, 27: $177-237$.

Orlicz-Luthardt, A. (1998). On the transfer of Fusarium wilt by seeds in China aster. Seed Science and Technology, 26: 67-76.

Zhang, Z. (1997). Effect of plant growth regulator and osmopriming on seed germination and seedling emergence of chosen flower species. M.Sc. dissertation. Poznań Agricultural University.

Table 1. The effect of microwave seed treatment on the total number of germinating seeds (Gmax) and seed germination capacity

\begin{tabular}{|c|c|c|c|c|c|c|c|}
\hline \multirow{2}{*}{\multicolumn{2}{|c|}{ Seed treatment }} & \multirow{2}{*}{\multicolumn{2}{|c|}{$\operatorname{Gmax}(\%)$}} & \multicolumn{4}{|c|}{ Germination capacity $(\%)$} \\
\hline & & & & \multicolumn{2}{|c|}{ I count } & \multicolumn{2}{|c|}{ II count } \\
\hline \multicolumn{2}{|l|}{ Control I* } & 89.0 & $f^{* *}$ & 64.7 & gh & 70.3 & gh \\
\hline \multicolumn{2}{|l|}{ Control II } & 75.0 & de & 54.7 & cdef & 61.3 & efg \\
\hline \multirow{9}{*}{$\begin{array}{l}\text { Dry } \\
\text { microwave } \\
\text { seed } \\
\text { treatment }\end{array}$} & $10 \mathrm{~s}$ & 82.3 & def & 63.0 & fgh & 67.0 & fgh \\
\hline & $20 \mathrm{~s}$ & 84.3 & ef & 64.0 & fgh & 68.7 & gh \\
\hline & $30 \mathrm{~s}$ & 57.7 & $\mathrm{c}$ & 63.3 & fgh & 66.7 & fgh \\
\hline & $40 \mathrm{~s}$ & 49.3 & $\mathrm{c}$ & 45.7 & $\mathrm{c}$ & 47.3 & $\mathrm{c}$ \\
\hline & $50 \mathrm{~s}$ & 56.0 & $\mathrm{c}$ & 47.0 & $\mathrm{c}$ & 50.3 & $\mathrm{~cd}$ \\
\hline & $60 \mathrm{~s}$ & 39.0 & $\mathrm{~b}$ & 11.7 & $\mathrm{~b}$ & 12.3 & $\mathrm{~b}$ \\
\hline & $90 \mathrm{~s}$ & 55.3 & $\mathrm{c}$ & 61.0 & efgh & 63.7 & efgh \\
\hline & $120 \mathrm{~s}$ & 0 & $a$ & 8.3 & $\mathrm{~b}$ & 12.3 & $\mathrm{~b}$ \\
\hline & $180 \mathrm{~s}$ & 0 & $\mathrm{a}$ & 0 & $\mathrm{a}$ & 0 & $a$ \\
\hline \multirow{9}{*}{$\begin{array}{l}\text { Microwave } \\
\text { seed } \\
\text { treatment in } \\
\text { water }\end{array}$} & $10 \mathrm{~s}$ & 81.0 & def & 53.0 & $\mathrm{~cd}$ & 57.7 & def \\
\hline & $20 \mathrm{~s}$ & 81.0 & def & 58.0 & efg & 65.0 & efgh \\
\hline & $30 \mathrm{~s}$ & 77.3 & de & 61.0 & efgh & 70.0 & gh \\
\hline & $40 \mathrm{~s}$ & 80.7 & def & 57.7 & defg & 62.7 & efg \\
\hline & $50 \mathrm{~s}$ & 81.7 & def & 69.0 & $\mathrm{~h}$ & 72.3 & $\mathrm{~h}$ \\
\hline & $60 \mathrm{~s}$ & 76.3 & de & 66.3 & gh & 69.3 & gh \\
\hline & $90 \mathrm{~s}$ & 73.7 & $\mathrm{~d}$ & 48.7 & $\mathrm{~cd}$ & 56.7 & de \\
\hline & $120 \mathrm{~s}$ & 28.7 & $\mathrm{~b}$ & 11.0 & $\mathrm{~b}$ & 15.3 & $\mathrm{~b}$ \\
\hline & $180 \mathrm{~s}$ & 0 & $\mathrm{a}$ & 0 & $\mathrm{a}$ & 0 & $\mathrm{a}$ \\
\hline
\end{tabular}

* Control I - untreated seeds; Control II - seeds treated with Kaptan Zawiesinowy 50WP; dry microwave seed treatment for 10,20,30,40,50,60,90,120 and 180 s respectively; microwave seed treatment in water for 10, 20, $30,40,50,60,90,120$ and 180 s respectively;

** Mean in columns follow by the same letters are not significantly different at $\alpha=0.05$ level according to Duncan's multiple range test 
Table 2. The effect of microwave seed treatment on the number of abnormal seedlings, dead seeds and fresh ungerminated seeds

\begin{tabular}{|c|c|c|c|c|}
\hline \multicolumn{2}{|c|}{ Seed treatment } & $\begin{array}{c}\text { Abnormal seedlings } \\
(\%)\end{array}$ & Dead seeds $(\%)$ & $\begin{array}{c}\text { Fresh ungerminated } \\
\text { seeds }(\%)\end{array}$ \\
\hline \multicolumn{2}{|l|}{ Control I* } & $5.3 \quad \mathrm{~b}$ & $21.7 \mathrm{~cd}$ & $2.7 \quad \mathrm{ab}$ \\
\hline \multicolumn{2}{|l|}{ Control II } & $6.7 \quad b$ & $10.3 \quad \mathrm{a}$ & $21.7 \mathrm{~g}$ \\
\hline \multirow{9}{*}{$\begin{array}{l}\text { Dry } \\
\text { microwave } \\
\text { seed } \\
\text { treatment }\end{array}$} & $10 \mathrm{~s}$ & 5.0 & $25.3 \mathrm{~d}$ & $2.7 \quad a b$ \\
\hline & $20 \mathrm{~s}$ & 5.3 & 20.0 bcd & $6.0 \mathrm{~cd}$ \\
\hline & $30 \mathrm{~s}$ & 5.0 & $25.3 \mathrm{~d}$ & $1.7 \quad \mathrm{a}$ \\
\hline & $40 \mathrm{~s}$ & 9.3 bc & $39.0 \mathrm{f}$ & 4.3 abcd \\
\hline & $50 \mathrm{~s}$ & $9.0 \mathrm{bc}$ & 38.0 ef & 2.7 abcd \\
\hline & $60 \mathrm{~s}$ & 7.3 & $74.8 \mathrm{~h}$ & 6.0 cde \\
\hline & $90 \mathrm{~s}$ & 5.3 & $27.7 \mathrm{de}$ & abcd \\
\hline & $120 \mathrm{~s}$ & 19.3 & $62.7 \mathrm{~g}$ & 5.7 \\
\hline & $180 \mathrm{~s}$ & 0.7 & $87.0 \quad \mathrm{i}$ & 12.3 ef \\
\hline \multirow{9}{*}{$\begin{array}{l}\text { Microwave } \\
\text { seed } \\
\text { treatment in } \\
\text { water }\end{array}$} & $10 \mathrm{~s}$ & 7.3 & $28.0 \mathrm{de}$ & 7.0 de \\
\hline & $20 \mathrm{~s}$ & 10.0 & $20.0 \mathrm{~cd}$ & 5.0 bcde \\
\hline & $30 \mathrm{~s}$ & 12.7 & $11.7 \mathrm{ab}$ & $5.7 \quad$ cde \\
\hline & $40 \mathrm{~s}$ & 10.3 & $21.3 \mathrm{~cd}$ & bcde \\
\hline & $50 \mathrm{~s}$ & 9.0 & 16.7 abcd & cde \\
\hline & $60 \mathrm{~s}$ & 9.3 & $14.0 \quad \mathrm{abc}$ & 7.3 \\
\hline & $90 \mathrm{~s}$ & 9.8 & 18.0 abcd & 14.0 \\
\hline & $120 \mathrm{~s}$ & 6.0 & 20.7 cd & 58.0 \\
\hline & $180 \mathrm{~s}$ & 0.3 & $43.3 \mathrm{f}$ & 54.7 \\
\hline
\end{tabular}

* For explanation see Table. 1

Table 3. The effect of microwave seed treatment on the seed vigour - time to 1,10 and $25 \%$ of the maximum germination (days)

\begin{tabular}{|c|c|c|c|c|c|}
\hline \multirow{2}{*}{\multicolumn{2}{|c|}{$\begin{array}{l}\text { Seed treatment } \\
\text { Control I** }\end{array}$}} & $\mathrm{T}_{1} *$ & $\mathrm{~T}_{10}$ & & \\
\hline & & $1.37 \mathrm{ab}$ & $1.70 \quad \mathrm{a}$ & 1.95 & abcd \\
\hline \multicolumn{2}{|l|}{ Control II } & $1.36 \mathrm{ab}$ & 1.79 & 2.16 & $\mathrm{~d}$ \\
\hline \multirow{9}{*}{$\begin{array}{l}\text { Dry } \\
\text { microwave } \\
\text { seed } \\
\text { treatment }\end{array}$} & $10 \mathrm{~s}$ & $1.26 \mathrm{ab}$ & 1.51 & 1.70 & $\mathrm{a}$ \\
\hline & $20 \mathrm{~s}$ & 1.26 & 1.54 & 1.77 & $a b$ \\
\hline & $30 \mathrm{~s}$ & $1.16 \mathrm{ab}$ & 1.66 & 2.07 & abcd \\
\hline & $40 \mathrm{~s}$ & 1.61 & 1.84 & 2.28 & $\mathrm{~d}$ \\
\hline & $50 \mathrm{~s}$ & $1.30 \quad \mathrm{ab}$ & 1.63 & 1.91 & $a b c$ \\
\hline & $60 \mathrm{~s}$ & $1.24 \mathrm{ab}$ & 1.74 & 2.28 & d \\
\hline & $90 \mathrm{~s}$ & $1.09 \mathrm{a}$ & 1.71 & 2.03 & abcd \\
\hline & $120 \mathrm{~s}$ & $-* * *$ & - & & \\
\hline & $180 \mathrm{~s}$ & - & - & & \\
\hline \multirow{9}{*}{$\begin{array}{l}\text { Microwave } \\
\text { seed } \\
\text { treatment in } \\
\text { water }\end{array}$} & $10 \mathrm{~s}$ & $1.19 \quad \mathrm{ab}$ & $1.60 \mathrm{a}$ & 1.87 & $a b c$ \\
\hline & $20 \mathrm{~s}$ & 1.50 & 1.76 & 1.96 & abcd \\
\hline & $30 \mathrm{~s}$ & 1.17 & 1.61 & 1.95 & abcd \\
\hline & $40 \mathrm{~s}$ & 1.16 & 1.55 & 1.79 & $\mathrm{ab}$ \\
\hline & $50 \mathrm{~s}$ & $1.28 \mathrm{ab}$ & 1.51 & 1.77 & $a b$ \\
\hline & $60 \mathrm{~s}$ & $1.47 \mathrm{ab}$ & 1.61 & 1.92 & $a b c$ \\
\hline & $90 \mathrm{~s}$ & 1.32 & 1.58 & 1.80 & $a b$ \\
\hline & $120 \mathrm{~s}$ & $1.43 \mathrm{ab}$ & $2.41 \quad \mathrm{~b}$ & 3.26 & $\mathrm{e}$ \\
\hline & $180 \mathrm{~s}$ & - & - & & \\
\hline
\end{tabular}

* T1 - time to $1 \%$ of maximum germination, $\mathrm{T} 10$ - time to $10 \%$ of maximum germination, $\mathrm{T} 25$ - time to $25 \%$ of maximum germination

** For further explanation see Table 1

*** Seeds did not germinate 
Table 4. The effect of microwave seed treatment on the seed vigour - time to 50,75 and $90 \%$ of the maximum germination (days)

\begin{tabular}{|c|c|c|c|c|c|c|c|}
\hline \multicolumn{2}{|l|}{ Seed treatment } & $\mathrm{T}_{50} *$ & & $\mathrm{~T}_{75}$ & & $\mathrm{~T}_{90}$ & \\
\hline \multicolumn{2}{|l|}{ Control I** } & 2.34 & abcd & 3.14 & $\mathrm{a}$ & 4.63 & $a b$ \\
\hline \multicolumn{2}{|l|}{ Control II } & 2.87 & $\mathrm{e}$ & 4.41 & $\mathrm{~d}$ & 6.85 & ef \\
\hline \multirow{9}{*}{$\begin{array}{l}\text { Dry microwave } \\
\text { seed treatment }\end{array}$} & $10 \mathrm{~s}$ & 2.03 & $\mathrm{a}$ & 2.82 & $\mathrm{a}$ & 4.24 & $\mathrm{a}$ \\
\hline & $20 \mathrm{~s}$ & 2.13 & $\mathrm{a}$ & 2.92 & $\mathrm{a}$ & 4.51 & $a b$ \\
\hline & $30 \mathrm{~s}$ & 2.50 & abcd & 4.11 & bcd & 6.16 & def \\
\hline & $40 \mathrm{~s}$ & 2.78 & bcde & 4.28 & $\mathrm{~cd}$ & 7.03 & $\mathrm{f}$ \\
\hline & $50 \mathrm{~s}$ & 2.40 & abcd & 3.60 & $a b c$ & 5.71 & bcde \\
\hline & $60 \mathrm{~s}$ & 3.05 & $\mathrm{e}$ & 4.25 & $\mathrm{~cd}$ & 6.23 & def \\
\hline & $90 \mathrm{~s}$ & 2.78 & cde & 4.08 & bcd & 5.97 & cdef \\
\hline & $120 \mathrm{~s}$ & $-* * *$ & & - & & - & \\
\hline & $180 \mathrm{~s}$ & - & & - & & - & \\
\hline \multirow{9}{*}{$\begin{array}{l}\text { Microwave } \\
\text { seed treatment } \\
\text { in water }\end{array}$} & $10 \mathrm{~s}$ & 2.33 & abcd & 3.20 & $\mathrm{a}$ & 4.94 & $a b c$ \\
\hline & $20 \mathrm{~s}$ & 2.29 & abcd & 3.20 & $\mathrm{a}$ & 4.87 & $\mathrm{abc}$ \\
\hline & $30 \mathrm{~s}$ & 2.47 & abcd & 3.44 & $a b$ & 5.06 & abcd \\
\hline & $40 \mathrm{~s}$ & 2.25 & $a b c$ & 3.19 & $\mathrm{a}$ & 4.91 & $\mathrm{abc}$ \\
\hline & $50 \mathrm{~s}$ & 2.15 & $\mathrm{a}$ & 3.14 & $\mathrm{a}$ & 4.72 & $a b c$ \\
\hline & $60 \mathrm{~s}$ & 2.30 & $a b c$ & 3.53 & $a b c$ & 5.67 & bcde \\
\hline & $90 \mathrm{~s}$ & 2.20 & $a b$ & 3.25 & $\mathrm{a}$ & 5.26 & abcd \\
\hline & $120 \mathrm{~s}$ & 4.54 & $\mathrm{f}$ & 6.04 & $\mathrm{e}$ & 9.53 & $\mathrm{~g}$ \\
\hline & $180 \mathrm{~s}$ & - & & - & & - & \\
\hline
\end{tabular}

* $\mathrm{T}_{50}$ - time to $50 \%$ of maximum germination, $\mathrm{T}_{75}$ - time to $75 \%$ of maximum germination, $\mathrm{T}_{90}-$ time to $90 \%$ of maximum germination

** For further explanation see Table 1

*** Seeds did not germinate

Table 5. The effect of microwave seed treatment on the mean germination time and uniformity of germination (days)

\begin{tabular}{|c|c|c|c|c|c|c|}
\hline \multirow{2}{*}{\multicolumn{2}{|c|}{ Seed treatment }} & \multirow{2}{*}{$\mathrm{MGT}^{*}$} & \multicolumn{4}{|c|}{ Uniformity of germination } \\
\hline & & & \multicolumn{2}{|c|}{$\mathrm{U}_{75-25}$} & \multicolumn{2}{|c|}{$\mathrm{U}_{90-10}$} \\
\hline \multicolumn{2}{|l|}{ Control I** } & $2.84 \quad a b$ & 1.19 & $\mathrm{ab}$ & 2.94 & \\
\hline \multicolumn{2}{|l|}{ Control II } & $3.75 \mathrm{e}$ & 2.32 & $\mathrm{~cd}$ & 5.06 & $f$ \\
\hline \multirow{9}{*}{$\begin{array}{l}\text { Dry microwave } \\
\text { seed treatment }\end{array}$} & $10 \mathrm{~s}$ & 2.54 & 1.11 & $\mathrm{a}$ & 2.73 & $\mathrm{a}$ \\
\hline & $20 \mathrm{~s}$ & $2.66 \quad \mathrm{ab}$ & 1.15 & $\mathrm{a}$ & 2.96 & $\mathrm{ab}$ \\
\hline & $30 \mathrm{~s}$ & 3.45 cde & 2.05 & $\mathrm{a}$ & 4.39 & cdef \\
\hline & $40 \mathrm{~s}$ & 3.65 & 2.24 & $\mathrm{~d}$ & 5.19 & $\mathrm{f}$ \\
\hline & $50 \mathrm{~s}$ & 3.16 bcd & 1.69 & abcd & 4.08 & bcdef \\
\hline & $60 \mathrm{~s}$ & $3.52 \mathrm{de}$ & 1.97 & $\mathrm{~cd}$ & 4.18 & bcdef \\
\hline & $90 \mathrm{~s}$ & $3.49 \mathrm{de}$ & 1.96 & $\mathrm{~cd}$ & 4.52 & def \\
\hline & $120 \mathrm{~s}$ & $-* * *$ & & & & \\
\hline & $180 \mathrm{~s}$ & - & & & & \\
\hline \multirow{9}{*}{$\begin{array}{l}\text { Microwave } \\
\text { seed treatment } \\
\text { in wate }\end{array}$} & $10 \mathrm{~s}$ & $2.82 \quad \mathrm{ab}$ & 1.33 & $\mathrm{abc}$ & 3.15 & $\mathrm{abc}$ \\
\hline & $20 \mathrm{~s}$ & $2.89 \quad \mathrm{ab}$ & 1.17 & $\mathrm{a}$ & 3.11 & $\mathrm{ab}$ \\
\hline & $30 \mathrm{~s}$ & $3.00 \quad a b c$ & 1.49 & $a b c$ & 3.46 & abcd \\
\hline & $40 \mathrm{~s}$ & $2.83 \quad a b$ & 1.41 & $a b c$ & 3.42 & abcd \\
\hline & $50 \mathrm{~s}$ & $2.82 \quad a b$ & 1.42 & $a b c$ & 3.39 & abcd \\
\hline & $60 \mathrm{~s}$ & 3.12 bcd & 1.61 & $a b c$ & 3.96 & abcde \\
\hline & $90 \mathrm{~s}$ & $2.91 \quad \mathrm{ab}$ & 1.45 & $a b c$ & 3.68 & abcd \\
\hline & $120 \mathrm{~s}$ & $5.39 \mathrm{f}$ & 3.37 & $\mathrm{e}$ & 7.12 & g \\
\hline & $180 \mathrm{~s}$ & - & & & & \\
\hline
\end{tabular}

* MGT - mean germination time, U75-25 - time between $25 \%$ and $75 \%$ of maximum germination; U90-10 time between $10 \%$ and $90 \%$ of maximum germination

**For further explanation see Table 1

*** Seeds did not germinate 
Table 6. The effects of microwave seed treatment on their infestation with Alternaria alternata, Cladosporium spp. and Penicillium spp.

\begin{tabular}{|c|c|c|c|c|}
\hline \multirow{2}{*}{\multicolumn{2}{|c|}{ Seed treatment }} & \multicolumn{3}{|c|}{ Seed infestation with (\%) } \\
\hline & & Alternaria alternata & Cladosporium spp. & Penicillium spp. \\
\hline \multicolumn{2}{|l|}{ Control I* } & 39.0 efg & $2.5 \mathrm{~cd}$ & 3.5 abcde \\
\hline \multicolumn{2}{|l|}{ Control II } & $9.5 \mathrm{~b}$ & $0.5 \mathrm{ab}$ & $0.5 \mathrm{a}$ \\
\hline \multirow{9}{*}{$\begin{array}{l}\text { Dry } \\
\text { microwave } \\
\text { seed } \\
\text { treatment }\end{array}$} & $10 \mathrm{~s}$ & $47.0 \mathrm{~g}$ & 1.5 abcd & $1.5 \mathrm{abc}$ \\
\hline & $20 \mathrm{~s}$ & $42.0 \quad \mathrm{fg}$ & $\begin{array}{ll}0 & \mathrm{a} \\
\end{array}$ & $2.0 \quad \mathrm{ab}$ \\
\hline & $30 \mathrm{~s}$ & $40.5 \quad \mathrm{fg}$ & $0.5 \quad \mathrm{ab}$ & $1.0 \mathrm{a}$ \\
\hline & $40 \mathrm{~s}$ & 28.5 cde & $0 \quad \mathrm{a}$ & $5.0 \quad$ cdefg \\
\hline & $50 \mathrm{~s}$ & $40.0 \quad \mathrm{fg}$ & $1.0 \quad \mathrm{abc}$ & 11.5 fg \\
\hline & $60 \mathrm{~s}$ & 32.5 def & $1.0 \mathrm{abc}$ & 7.5 efg \\
\hline & $90 \mathrm{~s}$ & 35.0 ef & 3.5 & 6.5 defg \\
\hline & $120 \mathrm{~s}$ & 19.5 & $2.0 \quad$ abcd & 6.5 defg \\
\hline & $180 \mathrm{~s}$ & $4.5 \mathrm{~b}$ & $0 \quad \mathrm{a}$ & 5.0 bcdef \\
\hline \multirow{9}{*}{$\begin{array}{l}\text { Microwave } \\
\text { seed } \\
\text { treatment in } \\
\text { water }\end{array}$} & $10 \mathrm{~s}$ & 36.5 efg & 1.5 abcd & $13.0 \quad \mathrm{~g}$ \\
\hline & $20 \mathrm{~s}$ & 35.5 efg & 0 & 7.0 efg \\
\hline & $30 \mathrm{~s}$ & 37.5 efg & $2.0 \mathrm{bcd}$ & 6.0 defg \\
\hline & $40 \mathrm{~s}$ & 37.5 efg & $0.5 \mathrm{ab}$ & $3.0 \quad$ abcde \\
\hline & $50 \mathrm{~s}$ & 34.0 ef & 0 & defg \\
\hline & $60 \mathrm{~s}$ & $22.5 \mathrm{~cd}$ & 2.0 bcd & 3.5 abcde \\
\hline & $90 \mathrm{~s}$ & $26.5 \mathrm{~cd}$ & 1.0 & abcde \\
\hline & $120 \mathrm{~s}$ & 0 & 0 & 0.5 \\
\hline & $180 \mathrm{~s}$ & $\mathrm{a}$ & 2.0 bcd & 2.0 abcd \\
\hline
\end{tabular}

* For explanation see Table 1

Table 7. The effects of microwave seed treatment on their infestation with Epicoccum purpurascens, Mucor sp. and Rhizopus nigricans.

\begin{tabular}{|c|c|c|c|c|c|c|c|}
\hline \multirow{3}{*}{\multicolumn{2}{|c|}{ Seed treatment }} & \multicolumn{6}{|c|}{ Seed infestation with (\%) } \\
\hline & & \multicolumn{2}{|c|}{$\begin{array}{l}\text { Epicoccum } \\
\text { purpurascens }\end{array}$} & \multicolumn{2}{|c|}{ Mucor sp. } & \multicolumn{2}{|c|}{ Rhizopus nigricans } \\
\hline & & 2.0 & $\mathrm{a}$ & 1.0 & $\mathrm{ab}$ & 1.0 & $\mathrm{a}$ \\
\hline \multicolumn{2}{|l|}{ Control II } & 0 & $\mathrm{a}$ & 1.0 & $a b$ & 0 & $\mathrm{a}$ \\
\hline \multirow{9}{*}{$\begin{array}{l}\text { Dry } \\
\text { microwave } \\
\text { seed } \\
\text { treatment }\end{array}$} & $10 \mathrm{~s}$ & 1.5 & $\mathrm{a}$ & 0 & $\mathrm{a}$ & 0 & $\mathrm{a}$ \\
\hline & $20 \mathrm{~s}$ & 0 & $\mathrm{a}$ & 0 & $\mathrm{a}$ & 0.5 & $a b$ \\
\hline & $30 \mathrm{~s}$ & 0.5 & $\mathrm{a}$ & 0.5 & $a b$ & 0 & $\mathrm{a}$ \\
\hline & $40 \mathrm{~s}$ & 0.5 & $\mathrm{a}$ & 0 & $\mathrm{a}$ & 0 & $\mathrm{a}$ \\
\hline & $50 \mathrm{~s}$ & 1.5 & $\mathrm{a}$ & 0 & $\mathrm{a}$ & 0 & $\mathrm{a}$ \\
\hline & $60 \mathrm{~s}$ & 1.5 & $\mathrm{a}$ & 0.5 & $\mathrm{ab}$ & 3.0 & $\mathrm{bc}$ \\
\hline & $90 \mathrm{~s}$ & 1.0 & $\mathrm{a}$ & 0 & $\mathrm{a}$ & 0 & $\mathrm{a}$ \\
\hline & $120 \mathrm{~s}$ & 1.5 & $\mathrm{a}$ & 1.0 & $\mathrm{ab}$ & 0 & $\mathrm{a}$ \\
\hline & $180 \mathrm{~s}$ & 0.5 & $\mathrm{a}$ & 2.0 & $\mathrm{~b}$ & 1.0 & $\mathrm{abc}$ \\
\hline \multirow{9}{*}{$\begin{array}{l}\text { Microwave } \\
\text { seed } \\
\text { treatment in } \\
\text { water }\end{array}$} & $10 \mathrm{~s}$ & 1.0 & $\mathrm{a}$ & 1.5 & $\mathrm{~b}$ & 0.5 & $\mathrm{ab}$ \\
\hline & $20 \mathrm{~s}$ & 0 & $\mathrm{a}$ & 0 & $\mathrm{a}$ & 0 & $\mathrm{a}$ \\
\hline & $30 \mathrm{~s}$ & 1.0 & $\mathrm{a}$ & 0 & $\mathrm{a}$ & 0.5 & $\mathrm{ab}$ \\
\hline & $40 \mathrm{~s}$ & 0.5 & $\mathrm{a}$ & 0 & $\mathrm{a}$ & 1.0 & $\mathrm{ab}$ \\
\hline & $50 \mathrm{~s}$ & 0 & $\mathrm{a}$ & 0 & $\mathrm{a}$ & 0 & $\mathrm{a}$ \\
\hline & $60 \mathrm{~s}$ & 0 & $\mathrm{a}$ & 0 & $\mathrm{a}$ & 0 & $\mathrm{a}$ \\
\hline & $90 \mathrm{~s}$ & 0 & $\mathrm{a}$ & 1.0 & $\mathrm{a}$ & 0 & $\mathrm{a}$ \\
\hline & $120 \mathrm{~s}$ & 0 & $\mathrm{a}$ & 0 & $\mathrm{a}$ & 0 & $\mathrm{a}$ \\
\hline & $180 \mathrm{~s}$ & 0 & $\mathrm{a}$ & 0 & $\mathrm{a}$ & 2.0 & $a b c$ \\
\hline
\end{tabular}

* For explanation see Table 1 
Table 8. The effects of microwave seed treatment on their infestation with Curvularia sp., Ulocladium spp. and the number of seeds free from fungi

\begin{tabular}{|c|c|c|c|c|c|c|c|}
\hline \multirow{2}{*}{\multicolumn{2}{|c|}{ Seed treatment }} & \multicolumn{4}{|c|}{ Seed infestation with (\%) } & \multirow{2}{*}{\multicolumn{2}{|c|}{$\begin{array}{l}\text { Seeds free from fung } \\
(\%)\end{array}$}} \\
\hline & & \multicolumn{2}{|c|}{ Curvularia sp. } & \multicolumn{2}{|c|}{ Ulocladium spp. } & & \\
\hline \multicolumn{2}{|l|}{ Control I } & 0 & $\mathrm{a}$ & 0 & $\mathrm{a}$ & 53.5 & $\mathrm{abc}$ \\
\hline \multicolumn{2}{|l|}{ Control II } & 0 & $\mathrm{a}$ & 0 & $\mathrm{a}$ & 89.5 & $f$ \\
\hline \multirow{9}{*}{$\begin{array}{l}\text { Dry } \\
\text { microwave } \\
\text { seed } \\
\text { treatment }\end{array}$} & $10 \mathrm{~s}$ & 0.5 & $\mathrm{a}$ & 5.0 & d & 46.5 & $a b$ \\
\hline & $20 \mathrm{~s}$ & 0 & $\mathrm{a}$ & 3.5 & $\mathrm{~cd}$ & $\begin{array}{l}51.0 \\
\end{array}$ & $a b$ \\
\hline & $30 \mathrm{~s}$ & 0.5 & $\mathrm{a}$ & 2.0 & $\mathrm{bc}$ & 55.5 & $a b c$ \\
\hline & $40 \mathrm{~s}$ & 0.5 & $\mathrm{a}$ & 0 & $\mathrm{a}$ & 66.0 & cde \\
\hline & $50 \mathrm{~s}$ & 0.5 & $\mathrm{a}$ & 1.5 & $\mathrm{bc}$ & 46.0 & $\mathrm{a}$ \\
\hline & $60 \mathrm{~s}$ & 2.0 & $\mathrm{~b}$ & 1.0 & $a b c$ & 53.5 & $a b c$ \\
\hline & $90 \mathrm{~s}$ & 1.0 & $\mathrm{ab}$ & 1.0 & $a b c$ & 51.5 & $\mathrm{ab}$ \\
\hline & $120 \mathrm{~s}$ & 0.5 & $\mathrm{a}$ & 0 & $\mathrm{a}$ & 71.0 & de \\
\hline & $180 \mathrm{~s}$ & 0.5 & $\mathrm{a}$ & 0.5 & $\mathrm{ab}$ & 88.0 & $\mathrm{f}$ \\
\hline \multirow{9}{*}{$\begin{array}{l}\text { Microwave } \\
\text { seed } \\
\text { treatment in } \\
\text { water }\end{array}$} & $10 \mathrm{~s}$ & 0.5 & $\mathrm{a}$ & 0 & $\mathrm{a}$ & 50.5 & $a b$ \\
\hline & $20 \mathrm{~s}$ & 0.5 & $\mathrm{a}$ & 0 & $\mathrm{a}$ & 57.0 & $a b c$ \\
\hline & $30 \mathrm{~s}$ & 0 & $\mathrm{a}$ & 0 & $\mathrm{a}$ & 53.0 & $a b c$ \\
\hline & $40 \mathrm{~s}$ & 0 & $\mathrm{a}$ & 0.5 & $\mathrm{ab}$ & 56.0 & $a b c$ \\
\hline & $50 \mathrm{~s}$ & 0.5 & $\mathrm{a}$ & 0.5 & $a b$ & 60.0 & bcd \\
\hline & $60 \mathrm{~s}$ & 0 & $\mathrm{a}$ & 0 & $\mathrm{a}$ & 73.0 & cde \\
\hline & $90 \mathrm{~s}$ & 0 & $\mathrm{a}$ & 1.0 & $a b c$ & 68.0 & $\mathrm{e}$ \\
\hline & $120 \mathrm{~s}$ & 0 & $\mathrm{a}$ & 0 & $\mathrm{a}$ & 99.0 & $\mathrm{~g}$ \\
\hline & $180 \mathrm{~s}$ & 0 & $\mathrm{a}$ & 0.5 & $\mathrm{ab}$ & 91.5 & $\mathrm{f}$ \\
\hline
\end{tabular}

* For explanation see Table 1

Table 9. Moisture content of untreated seeds and seeds treated with dry microwave

\begin{tabular}{|l|l|l|}
\hline \multicolumn{2}{|l|}{ Seed treatment } & Moisture content (\%) \\
\hline \multicolumn{2}{|l|}{ Control I } & 6.60 \\
\hline \multirow{3}{*}{$\begin{array}{l}\text { Dry microwave seed } \\
\text { treatment }\end{array}$} & $10 \mathrm{~s}$ & 6.48 \\
\cline { 2 - 3 } & $20 \mathrm{~s}$ & 6.35 \\
\cline { 2 - 3 } & $30 \mathrm{~s}$ & 6.22 \\
\cline { 2 - 3 } & $40 \mathrm{~s}$ & 6.10 \\
\cline { 2 - 3 } & $50 \mathrm{~s}$ & 5.72 \\
\cline { 2 - 3 } & $60 \mathrm{~s}$ & 5.30 \\
\cline { 2 - 3 } & $90 \mathrm{~s}$ & 5.05 \\
\cline { 2 - 3 } & $120 \mathrm{~s}$ & 4.85 \\
\cline { 2 - 3 } & $180 \mathrm{~s}$ & 4.70 \\
\hline
\end{tabular}

* Control I - untreated seeds; dry microwave seed treatment for 10, 20, 30, 40, 50, 60, 90, 120 and $180 \mathrm{~s}$ respectively 